\title{
Strengthening Corporate Legal Functions in Achieving Good Corporate Governance at PT Bank Bengkulu
}

By :

Siti Aisyah Putri, Widiya N. Rosari, Tito Sofyan

\begin{abstract}
The increase in company value is reflected in the increase in performance and company image. PT Bank Bengkulu in enhancing the value of the company is done by applying the principles of Good corporate governance supported by the Corporate Legal division. The principles of Good Corporate Governance include: openness, accountability, responsibility, independence and fairness. Corporate Legal functions to regulate matters relating to the legal field which include: Organization and authority, advice or provision of legal assistance and handling legal cases, risk management and mitigation, documentation, administration and reporting. Previously, Corporate Legal was part of the Compliance Division. However, since the transfer of Corporate Legal to Corporate Secretary, there has been overlapping of authority, duties and functions. The problem in this research is how to strengthen Corporate Legal in realizing Good Corporate Governance and what are the factors that inhibit the strengthening of Corporate Legal function in realizing Good Corporate Governance at PT Bank Bengkulu. This type of research is empirical research, data sources obtained from interviews, documents, as well as literature and legislation relevant to research. The results of the study are the strengthening of Corporate Legal at PT Bank Bengkulu conducted by organizational restructuring based on Directors Decree No.17.1 / HP.00.01 / D.1 / 2019/2019 regarding changes in the organizational structure of the transfer of Corporate Legal to Corporate Secretary which was formerly Corporate Legal part of Compliance division, this transfer makes Corporate Legal have a wider authority that is able to provide legal oponi which includes external banks where previously in compliance with Compliance, Corporate Legal can only provide legal opinions that cover only the internal parts of the bank. The factor that inhibits the strengthening of the function of Corporate Legal in realizing good corporate governance at PT Bank Bengkulu is the overlapping authority between the Compliance division and the Corporate Secretary, in which there are no restrictions on what should be reviewed by the Compliance Division and Corporate Secretary, then in policy taken by the Board of Directors cannot be immediately decided by Corporate Legal so the problem becomes slow to be resolved immediately.
\end{abstract}

Keywords: Legal Corporate, Good Corporate Governance, PT Bank Bengkulu 


\section{A. INTRODUCTION}

\section{Research Background}

Based on Article 1 Number 6 of Bank of Indonesia Regulation Number 8/4/ PBI/2006 concerning Implementation of Good Corporate Governance for Commercial Banks, Good Corporate Governance is a Bank governance that applies the principles of transparency, accountability, responsibility, independency, and fairness.

The implementation of good corporate governance in banking is considered unique because it has different characteristics from other types of financial companies and nonfinancial companies. The uniqueness of banks is mainly seen from the balance sheet that is the average banking assets are loans that are mostly long-term, while the liabilities side is savings and deposits that have a short-term nature. Careless management will cause a mismatch between assets and liabilities. The occurrence of mismatch can cause negative bookkeeping for banks. Credit distribution to related parties can be positive if the relationship minimizes risk, and vice versa, it will be negative if it increases the risk of default due to moral hazard. However, Good Corporate Governance becomes thick when there is a conflict of interests between the owner and the management. ${ }^{1}$

In an effort to increase company value, which is reflected in the form of increased performance (high performance) and corporate image (good corporate image), Good Corporate Governance is one of the ways taken by PT Bank Bengkulu.

PT Bank Bengkulu is a regional development bank that aims to encourage economic growth in the region by developing the business world in general, especially small and medium businesses and cooperatives, based on the principles of compliance, prudence, Good Corporate Governance, and the commitment of all management and employees.

PT Bank Bengkulu, in realizing the principles of good corporate governance, is supported by the Corporate

${ }^{1}$ Andrianto, Manajemen Bank Syariah, Qiara Media, Jakarta, 2019, p.340. 
Secretary division which includes the Corporate Legal section, which used to be part of the Compliance Division, but since January 25, 2019, there was a change in the organizational structure, namely the formation of the Corporate Secretary Division with Corporate Legal within. However, in practice, the Compliance Division is still handling/doing work that has been delegated to the Corporate Legal section so that there is an overlap of authority between the Compliance division and Corporate Legal.

Corporate Legal functions to regulate external issues related to the legal field which include: Organization and authority, advice or provision of legal assistance and the handling of legal cases, risk management and mitigation, documentation, administration and reporting.

\section{Problems Identification}

1. What were the factors that inhibit the strengthening of corporate legal function in realizing good corporate governance at PT Bank Bengkulu?
2. How was the strengthening of Corporate Legal in realizing good corporate governance at PT Bank Bengkulu?

\section{Research Purposes}

1. To know and to understand the strengthening of corporate legal function in realizing good corporate governance at PT Bank Bengkulu.

2. To find out and to understand the factors that hinder the strengthening of corporate legal function in realizing good corporate governance at PT Bank Bengkulu.

\section{B. RESEARCH METHOD}

The type of research applied in this study was empirical legal research. Empirical legal research is one type of legal research that analyzes and examines the operation of law in society. ${ }^{2}$

Sources of data used in the study were primary and secondary data sources. Primary data sources are data derived from field data. The field data was obtained from respondents. ${ }^{3}$ In

\footnotetext{
${ }^{2}$ Ishaq, Metode Penelitian Hukum dan Penulisan Skripsi, Tesis, Serta Disertasi, Alfabeta, Bandung, 2016, p.70.
}

${ }^{3}$ Salim HS and Erlies Septiana Narbani, 
this case the respondents of this study were PT Bank Bengkulu's Compliance Director, PT Bank Bengkulu Corporate Secretary Division Leader, and PT Bank Bengkulu Corporate Legal Division Leader. Secondary data are the data obtained from library studies by conducting library research aimed at finding data in the form of theories, opinions, views, and legal principles that are closely related to the subject matter being studied. ${ }^{4}$

\section{RESEARCH RESULTS AND DISCUSSION}

\section{A. Strengthening the Corporate}

Legal Function in Realizing Good Corporate Governance at PT Bank Bengkulu

Bank Bengkulu is a Bengkulu regional development bank which was established on August 9, 1969 based on the Decree on the Governor of Bengkulu Province Number: 08/14/EKU/1969, which was ratified by the Minister of Home Affairs of the Republic of Indonesia with Decree Number: 14/4/1323 dated on 29 November

Penerapan Teori Hukum Pada Penelitian Tesis dan Disertasi, PT Raja Grafindo Persada, Jakarta, 2013, p.25.

\footnotetext{
${ }^{4}$ Ibid, p. 26.
}

1969, which was subsequently granted an in-principle license with the Decree of the Minister of Finance of the Republic of Indonesia Number: D-15-6.1.25 dated on May 17, 1970. Bank Bengkulu began to be inaugurated on April 13, 1971. This matter was written in the Decree of the Minister of Finance of the Republic Indonesia Number: Kep102/DDK/II/4/1971. On April 1, 1971, Bengkulu Regional Development Bank started its business as a Bank Financial Institution. ${ }^{5}$

PT. Bank Bengkulu with its head office located at Jalan S. Parman Bengkulu city has a policy in its company that is developing the business world in general, especially small and medium businesses (SMEs) and cooperatives, based on the principles of compliance, prudence, good corporate governance and commitment from all management and employees supported by the Corporate Secretary division of the Corporate Legal section.

\footnotetext{
${ }^{5}$ https://www.bankbengkulu.co.id/ accessed at $10^{\text {th }}$ of April 2020 at 10.38 a.m.
} 
In Article 1 of the Financial Services Authority Regulation Number 35/Pojk.04/2014 regarding the Corporate Secretary of Issuers or Public Companies, the Corporate Secretary is:

The Company Secretary is an individual or person in charge of a work unit that carries out the function of the company secretary.

\section{The Corporate Secretary}

of Bank Bengkulu which is usually called corsec has an important role in the implementation of good corporate governance. The Corsec has 2 parts, namely Corporate Communication and Seretary and Corporate Legal. The functions of the Corporate Legal of PT Bank Bengkulu are: ${ }^{6}$ Carry out regulatory functions (preparation and issuance of provisions) in the field of law, Carry out litigation and non-litigation functions in handling criminal and noncriminal legal cases in accordance

\footnotetext{
${ }^{6}$ Data on PT Bank Bengkulu Guidebook
}

with the criteria for handling cases that are their duties and responsibilities, and carrying out functions of assistance, advocacy or provision of legal assistance for all levels of the Bank in fulfilling the summons of Law Enforcement Officials.

PT Bank Bengkulu as a banking institution, seeks to create good corporate governance by creating good security, building public trust and maintaining customer financial transactions. In addition, Corporate Legal is expected to be able to provide input on the effectiveness of solving problems arising in the field of banking crime, overseeing the effectiveness of the company in order to reduce and overcome all possible customers who have bad intentions and result in reduced profits / corporate earnings. These steps are carried out aimed at strengthening the function of Corporate Legal at PT Bank Bengkulu in order to fulfill the principles of good corporate governance, namely transparency, accountability, responsibility, independence, and fairness in carrying out business activities.

\section{A. Obstacles in Applying}


Corporate Legal to PT Bank

\section{Bengkulu}

As an intermediary and trust institution, in carrying out its business activities, banks must adhere to the principle of openness (transparency), have performance measures from all levels of the bank based on measures consistent with corporate values, business objectives and bank strategies as a reflection of bank accountability (accountability), adhere to prudential banking practices and ensure the implementation of the provisions that apply as a form of bank responsibility (objective), objective and free from pressure from any party in making decisions (independence), and always pay attention to the interests of all stakeholders based on the principle of equality and fairness.

Good corporate governance can provide a frame of reference that allows effective monitoring, so that checks and balances can be created in the company. ${ }^{7}$ The implementation of good corporate governance needs to be supported by three interconnected pillars, namely the state and its instruments as regulators, the business world as market participants, and the public as users of business products and services. Based on the Indonesian Banking of Good Corporate Governance Guidelines issued by the National Committee on Corporate Governance Policy on October $17^{\text {th }}, 2006$ the basic principles that must be implemented by each pillar are: ${ }^{8}$

1. The state and its instruments create laws and regulations that support a healthy, efficient and transparent business climate, implement regulations and consistent law enforcement.

2. The business world as a market participant applies

${ }^{7}$ The interview results with Roby Wijaya as Head of the Corporate Secretary Division of PT Bank Bengkulu On April 23 ${ }^{\text {rd }}, 2020$

${ }^{8}$ Governance Policy Committee General Guidelines for Good Corporate Governance in Indonesia https://panahperak.id/document/Indonesia_GCG.pd f downloaded on April $21^{\text {st }}, 2020$, at $7 \mathrm{pm}$ 
good

corporate

governance as a basic

guideline for business

implementation.

3. The community as users of business products and services as well as those affected by the existence of the company, show concern and exercise social control objectivelye and responsibly.

On January $25^{\text {th }}, 2019$, there was a change in the Organizational Structure at Bank Bengkulu through the Decree of the Board of Directors

No.17.1/HP.00.01/D.1/2019/ 2019 which was a change in the organizational structure and work procedures of the company by forming Corporate Legal as part of the Corporate Secretary. Previously, the Corporate Legal was part of the Compliance Division with the transfer of Corporate Legal, sometimes there is

still overlap in the authority of the Corporate Secretary of the Corporate Legal section with the Compliance Division. ${ }^{9}$

The reason for the shifting of corporate legal from the compliance division to the Corporate Secretary is because the scope of the Compliance Division is limited to establishing systems and procedures that will be used to develop internal bank rules and guidelines. For this reason, PT Bank Bengkulu has added organizations / divisions, namely Corporate Secretary whose scope is broader so that it can cover both internal and external activities of the bank, where the Corporate Secretary has a Corporate Legal section. so that the joining of Corporate Legal becomes part of the Corporate Secretary, the activities and scope of Corporate Legal are broader, that is not only regulating the legal interests of the bank's internal alignment, but also regulating legal interests outside the bank's internal activities. i.e. by providing

\footnotetext{
${ }^{9}$ The Interview Results with Yanti Kurniati as Head of Compliance Division of PT Bank Bengkulu on April $23^{\text {rd }}, 2020$ at 3 pm.
} 
legal advice / opinion, assistance, advocacy or providing legal assistance to all bank staff in fulfilling the summons of law enforcement officials. Examples of cases that will be resolved by Corporate Legal through law enforcement agencies are if the customer experiences bad credit and has been rescued but there is no good faith from the customer and when traced a bilyet deposit that is used as a blank guarantee. Then, through the attorney of PT Bank Bengkulu reports the customer to the authorities.

In this case the Bank in carrying out its business needs to implement a precautionary principle as regulated in Article 2 of Act No. 10 of 1998 concerning Banking. To gain confidence and protect the bank as a creditor, the bank in this case must conduct a very good and thorough assessment of the prospective debtor's customers, known as the $5 \mathrm{C}$ principle of Character, Capability, Capital,
Guarantee Collateral) and the Economic Condition (Condition of Economy) of the prospective debtor. ${ }^{10}$ This is done to avoid and minimize the occurrence of bad loans.

PT Bank Bengkulu anticipates before the emergence or occurrence of bad loans by conducting a series of reviews of customer business development and credit development from the time it is given until paid off. The customer monitoring must be carried out by loan officer staff to see the business conditions of the debtor to be checked every month, every quarter and every semester and also to conduct credit analysis. The credit analysis is a credit assessment process in all aspects such as financial and non-financial. According to Lukman Dendawijaya, credit analysis is a form of credit analysis process using approaches and financial Bank Bengkulu on April $23^{\text {rd }}, 2020$ at 3 pm. 
ratios to determine reasonable credit needs. Besides paying attention to the above, the bank must know the purpose of using the credit and also the plan to develop its creditors and the urgency of the credit requested by the prospective debtor. The creditor usually also must recognize and see how the background of the prospective debtor's life. This is done to prevent the occurrence of problem loans in the future.

\section{CLOSING}

\section{Conclusion}

1) The strengthening of Corporate Legal in realizing good corporate governance at PT Bank Bengkulu is carried out by means of organizational restructuring based on Directors' Decree No.17.1 / HP.00.01 / D.1 / 2019/2019 concerning changes in organizational structure namely the transfer of Corporate Legal to Corporate Secretary previously Corporate Legal is part of the Compliance division, the transfer of
Corporate Legal to the Corporate Secretary makes Corporate Legal have broader authority, that is, it can provide legal opinions that cover the external activities of banks which were previously subject to Compliance, Corporate Legal can only provide legal opinions that cover the internal parts of the bank. Then the strengthening of Corporate Legal at PT Bank Bengkulu can be done by making regulations that give authority to Corporate Legal to determine the provision of legal advice / opinions themselves, so it does not have to be based on the approval of the directors.

2) Factors that hinder the strengthening of the function of Corporate Legal in realizing good corporate governance at PT Bank Bengkulu, namely:

1. There is an overlap in authority between the Compliance division and the Corporate Secretary. The overlap in authority occurs in 
the case of a

Cooperation Agreement $(P K S)$ review and a legal opinion review, which in this case there is no limit what should be reviewed by the Compliance Division and the Corporate Secretary. Then when both divisions are asked for legal opinions, sometimes both divisions have the same opinion which should the Compliance Division provide enough opinions that cover only the internal part of the bank. Then in the policies taken by the Directors cannot be immediately decided by Corporate Legal so that the problem becomes slow to be resolved immediately.

3) In terms of providing legal assistance for both criminal and civil cases, the appointment of an advocate proposed by Corporate Legal must be based on the approval of the Board of Directors, which in this agreement should hold a meeting of the board of directors which will take time so that the criminal or civil case will be slowly resolved.

\section{Suggestion}

1) PT. Bank Bengkulu can restructure the organization again by forming Corporate Legal into a separate division in order to carry out its functions and responsibilities to the maximum and is expected to be authorized by the directors to decide / determine the provision of advice / legal opinions themselves, so that the settlement of legal cases that occur at PT Bank Bengkulu can be resolved immediately, so that it can realize the creation of good corporate governance by meeting the principles of Good corporate governance, namely transparency, accountability, responsibility, independence, and fairness in carrying out business activities banking.

2) It is imperative that between Corporate Legal and 


\begin{abstract}
Compliance Division immediately make policies regarding what boundaries must be reviewed by the two divisions so that overlapping authority and accountability principles in good corporate governance can be fulfilled.
\end{abstract}

\section{Bibliography}

A. Books

Amir Machmud, 2010, Bank Syariah: Teori, Kebijakan, dan Studi Empiris Di Indonesia, Jakarta Erlangga

Andrianto, 2019, Manajemen Bank Syariah, Qiara Media, Jakarta.

Busyra Azheri, 2011, Corporate Social Responsibility Dari Voluntary Menjadi Mandotary, Jakarta, Raja Grafindo Perss, Jakarta.

Dosminikus Rato, 2010, Filasafat Hukum Mencari dan Memahami Hukum, Yogyakarta, PT Presindo.

Gunarto Suhardi, 2003, Usaha Perbankan Dalam Perspektif Hukum, Yogyakarta, PT Kanisius Ishaq, 2016, Metode Penelitian Hukum dan Penulisan Skrispsi, Tesis, Serta Disertasi, Alfabeta, Bandung.

Jimmy Joses Sembiring, 2009, Legal Officer, Jakarta, Trans Media Pustaka

Kasmir, 2015, Bank dan Lembaga Keuangan Lainnya, Jakarta, PT Raja Grafindo Persada.

M. Bahsan, 2015, Hukum Jaminan dan Jaminan Kredit Perbankan Indonesia, PT Rajawali Pers, Jakarta

Mal An Abdullah, 2010, Corporate Governance Perbankan Syariah Di
Indonesia ， Jakarta， PT Ar-Ruzz Media

Malayu SP Hasibuan, 2015, Dasar-Dasar Perbankan, Jakarta, PT Bumi Aksara

Mariam Darus Badrulzaman, 1994, Aneka Hukum Bisnis, Bandung, PT Alumni

Muhammad Syakir Sula, 2004, Asuransi Syariah (Life and General) Konsep dan Sistem Operasional, Jakarta , PT Gema Insani Pers.

Muhammad, 2005, Manajemen Bank Syariah, Yogyakarta, UPP AMP YKPN100

Neni Sri Imaniyati, 2010, Pengantar Hukum Perbankan Indonesia, Bandung, PT. Refika Aditama

Peter Mahmud Marzuki, 2008, Pengantar Ilmu Hukum, Jakarta, PT Kencana

Riduan Syahrani, 2002, Rangkuman Intisari

Ilmu Hukum, Bandung, Citra Aditya.

Salim HS, 2013, Penerapan Teori Hukum Pada Penelitian Tesis Dan Disertasi, Jakarta, PT Raja Grafindo Persada.

Try Widiyono, 2006, Aspek Hukum Operasional Transaksi Produk Perbankan Di Indonesia, Bogor, PT Ghalia Indonesia.

B. Journal

Zulfi Diane Zaini, Perspektif Hukum Sebagai Landasan Pembangunan Ekonomi Di Indonesia (Sebuah Pendekatan Filsafat), Jurnal Hukum, Vol XXVIII, No. 2, Desember 2012.

Dian Cahya Ningrum, Hambatan Implementasi Tata Kelola Perusahaan Yang Baik (Good Corporate Governance) Pada Badan Usaha Milik 
Negara (Bumn) Yang Berbentuk Persero, Jurnal Kajian Hukum, Vol 14 No 3, September 2009

C. Regulation

Undang-undang Republik Indonesia Nomor 27 Tahun 2007 tentang Perseroan Terbatas

Undang-undang Republik Indonesia Nomor 10 Tahun 1998 tentang Perubahan Atas Undang-Undang Nomor 7 Tahun 1992 tentang Perbankan.

Peraturan Bank Indonesia Nomor 8/4/Pbi/2006 tentang Pelaksanaan Good Corporate Governance Bagi Bank Umum.101

Surat Edaran Bank Indonesia Nomor 15/15/DPNP tanggal 29 April 2013 tentang Pelaksanaan Good Corporate Governance Bagi Bank Umum

D. Website

https://www.bi.go.id/id/tentangbi/manajeme nkrisis/jaringpengaman/Contents/Def ault.awpx

https://www.bi.go.id/id/peraturan/kodifikasi /bank/Pages/1347Good\%20Corporate \%20Governance.aspx

https://www.bankbengkulu.co.id/

http://www.knkgindonesia.org/dokumen/Pe doman-GCG-Perbankan.pdf

Ichsan Armanda, Implementasi Penegakan Prinsip Good Corporate Governance Perbankan (Tinjauan Terhadap Bank Mandiri) Universitas Indonesia, Program Pascasarjana Magister Ilmu Hukum, 2011,

http://lib.ui.ac.id/file?file=digital/20172/203 69852-T37688

Ichsan\%20Armanda.pdf , diakses pada 13 Januari 2020
Credo Media Vira Putra, Kedudukan Dan Fungsi Legal Officer Dalam Perseroan Terbatas, Universitas Sam Ratulangim Program Pascasarjana Magister Ilmu Hukum, 2013, file:///C:/Users/USER/Downloads/30655717-1-SM\%20.pdf , diakses pada 13 Januari 2020

Irmala Sari, Pengaruh Mekanisme Good Corporate Governance Terhadap Kinerja Perbankan Nasional (Studi pada Perusahaan Perbankan yang Terdaftar di Bursa Efek Indonesia Periode 2006-2008),Program Magister Ilmu Hukum 2010, http://eprints.undip.ac.id diakses pada 11 April 2020 